\title{
Az ajánlat hatálytalansága és érvénytelensége a közbeszerzési jogban Máté Gergö*
}

A közbeszerzési jog alapvetö elemének, az ajánlat fogalmának mélyebb megértését teszi lehetóvé érvénytelenségének, illetve hatálytalanságának megfelelö elhatárolása, amely végső soron az ajánlat eljárásjogi létezésének kérdését veti fel.

A tanulmány azt az általános elméleti következtetést vonja le az ajánlat példáján keresztül, hogy a jog(ügylet)i létezés (vagy nemlétezés) megállapitása egyrészt önálló, másrészt elsődleges döntést feltételez az érvényességének vagy érvénytelenségének megállapítását megelözően.

Kulcsszavak: ajánlat a közbeszerzési jogban, hatálytalan, érvénytelen, (nem)létezó

The ineffectiveness and invalidity of the offer in public procurement law

A better understanding of the offer in public procurement law can be attained, if we properly distinguish between its ineffectiveness and invalidity, which ultimately leads us to the question of its procedural existence.

The study asserts the general claim that the determination of the existence (or the inexistence) of a juridical act - in this case, the offer - is of primary importance preceding the validity/invalidity distinction. Keywords: offer in public procurement law, ineffective, invalid, (non)existent

https://doi.org/10.32980/MJSz.2021.3.1031

\section{Az ajánlat fogalma mint hiányzó fundamentum}

ligha tủnik túlzásnak a közbeszerzések világában az ajánlat Q megkerülhetetlenségét állítani, hiszen köztudottan a nyertes ajánlat tartalmának megfelelően kell megkötni - és persze később teljesíteni - a szerződést. Ha nincs ajánlat, amelyet nyertesként lehetne kihirdetni, esetleg ajánlatot sem tettek, úgy nem is lehet szerződni, tehát sok idő és energia veszett kárba. Márpedig az az általános tapasztalat, hogy egy múködő rendszerről beszélünk, ahol túlnyomó részt eredményes eljárásokat folytatnak le az ajánlatkérők függetlenül attól, hogy az "egyajánlatos" eljárások száma mekkora, és e tekintetben milyen arányszámmal lehetnénk (jogpolitikailag) megelégedve.

Érdemes rámutatunk arra a tényre is, hogy a polgári jog jelentős részét kitevő szerződések joga sem képzelhető el ajánlat nélkül még ott sem, ahol nem a szerződési szabadság, hanem a szerződéskötési kötelezettség érvényesül, hiszen a Ptk. 6:71. §-ának (2) bekezdése szerint a jogosult ajánlattételre hívhatja fel azt, akit

\footnotetext{
* Felelős akkreditált közbeszerzési szaktanácsadó.
} 
szerződéskötési kötelezettség terhel, és akinek a felhívás hatályossá válásától számított harminc napon belül kell az ajánlatát megtennie.

A hazai közbeszerzések területén kevésbé jártas megfigyelő azt gondolná tehát, hogy ami ennyire banális és hétköznapi, az nyilván egyértelmü és konkrét - nem érdemel különösebb figyelmet. Amennyiben viszont ez így van, akkor felmerül kérdés: a jogalkotó vajon miért nem adta meg egyszerüen az ajánlat fogalmát a közbeszerzésekröl szóló 2015. évi CXLIII. törvény (a továbbiakban Kbt.) több, mint negyven pontjából álló értelmező rendelkezéseiben, illetve a hazai szabályozás negyed évszázados múltja során, ahol még az olyan csekély jelentőséggel bíró fogalmak is definiáltak, mint például a keresleti vagy kínálati kockázat? Vélhetően ennek nem az az oka, hogy ne lenne gyakorlati haszna, hiszen az értelmezési különbségekből számos jogvita fakad, de talán azért sem, mert az ajánlat közbeszerzési fogalmának megalkotása eleve lehetetlen vállalkozás lenne.

Ugyan a jelen tanulmány nem vállalkozik a jelzett feladat elvégzésére, azonban az alapvető dogmatikai kategóriák vizsgálatával hozzá kíván járulni a tárgyi jogterületben benne rejlő - illetve azon túlmutató - fejlődési lehetőségek kihasználásához.

\section{Paradigmaváltás a közbeszerzési jogban}

Mielőtt részletesen foglalkoznék a tanulmány címében megjelölt témakörrel, szükségesnek tartom rögzíteni, hogy a hiányzó fundamentum lefektetése messzemenő következményekkel járhat.

Könnyen belátható, hogy az ajánlat fogalma érinti a közbeszerzési szerződést, a szakmai ajánlat és az ajánlati kötöttség fogalmát, amelyek szoros kapcsolatban állnak a hiánypótlás és számítási hiba javítása intézményével. Összefüggésben van továbbá az ajánlattétellel és az ajánlattal kapcsolatos egyéb ügyletekkel, mint amilyen az ajánlat módosítása, illetőleg visszavonása, hogy csak a legnyilvánvalóbbakat emeljem ki.

Az az állításom tehát, hogy amennyiben az ajánlat közbeszerzési fogalma megragadhatóvá válik, úgy az kihatással lesz szinte a teljes közbeszerzési eljárásra, illetve a legjelentősebb jogintézményekre, vagyis a közbeszerzés tulajdonképpen az uniós szabályozástól függetlenül - új alapokra helyeződne.

Egy, a témában készített korábbi munkámban ${ }^{1}$ már kifejtettem, hogy a fogalommeghatározást az ajánlat általános fogalmára építve, a Polgári Törvénykönyvröl szóló 2013. évi V. törvény (a továbbiakban Ptk.) dogmatikája alapján, ugyanakkor a közbeszerzési jog sajátosságaira figyelemmel célszerü elvégezni azzal, hogy a kérdés összetettségére tekintettel kerülendő az ad hoc szabályozás.

\footnotetext{
${ }^{1}$ MÁTÉ Gergő: Mi az ajánlat?, Közbeszerzési Szemle, 2017/1-2., 64-82. o.
} 


\section{Dogmatikai kulcskérdés: a hatályosság}

Meglátásom szerint a lehetséges paradigmaváltást a közbeszerzési jog dogmatikai megújulása hozhatja el, amely következetesen érvényesít alapvető, a jogbiztonságot szolgáló anyagi-, és eljárásjogi szabályokat.

Mindenekelött rögzíteni szükséges, hogy a hatályos Kbt. nem ismeri az ajánlat hatályosságának / hatálytalanságának kérdését ${ }^{2}$, vagyis az elkésett ajánlat is hatályosulhat és hatályos marad a visszavont ajánlat is azzal, hogy ezen „ajánlatokat" a Kbt. érvénytelenséggel szankcionálja. ${ }^{3}$

Elöljáróban szeretném jelezni, hogy a jelen tanulmányban képviselt dogmatika alapján az ajánlat hatályossága feltétel(rendszer)hez kötött, amely minden egyes eljárásban megtett ajánlat esetén vizsgálandó, mivel eljárásjogilag másként kezelendő a hatályos, illetve a hatálytalan ajánlat. A hatályosság feltételének a nem teljesítésülése azonban nem az ajánlat érvénytelenségét okozza, mivel annak eljárásjogi megállapítása nem lehetséges hatályos - tulajdonképpen eljárásjogilak létező - ajánlat hiányában.

A hatálytalanság és érvénytelenség viszonyának elméleti vizsgálata előtt próbáljuk értelmezni az ajánlat hatályossá és hatálytalanná válását.

\section{A Ptk. szerinti ajánlat, mint ajánlati kötöttség hatályossá válása}

A Ptk. az ajánlat fogalmát az ajánlati kötöttséggel azonosítja az alábbiak szerint: 6:64. \& [Ajánlati kötöttség]

(1) Aki szerződés megkötésére irányuló szándékát egyértelmüen kifejező és a lényeges kérdésekre kiterjedő jognyilatkozatot tesz, nyilatkozatához kötve marad. Az ajánlattevő kötöttségének idejét meghatározhatja.

(2) Az ajánlati kötöttség ideje az ajánlat hatályossá válásával veszi kezdetét.

A jognyilatkozat hatályossá válására vonatkozó általános szabályok az alábbiak. 6:5. \& [A jognyilatkozat hatályosulása]

(1) A jelenlevők között tett jognyilatkozat nyomban hatályossá válik. Jelenlévök között tett a jognyilatkozat abban az esetben, ha a jognyilatkozat tartalmáról a címzett annak megtételével egyidejüleg tudomást szerez.

(2) A távollevők között tett jognyilatkozat a címzetthez való megérkezéssel válik hatályossá.

(3) A ráutaló magatartással tett jognyilatkozat a címzett tudomásszerzésével válik hatályossá.

(4) A nem címzett jognyilatkozat megtételével válik hatályossá.

Összefoglalóan tehát az állapítható meg, hogy az ajánlat annak megtételével, tudomásra jutásával, illetve a tudomásra jutás lehetőségével hatályossá válik, vagyis

\footnotetext{
${ }^{2}$ Megjegyzem, nemcsak az ajánlat vonatkozásában érvényes a megállapítás - általánosságban az eljárás során tett jognyilatkozatokra érthetjük.

${ }^{3}$ Kbt. 73. § (1) bekezdés, a) pont és (6) bekezdés, a) pont
} 
amikor a címzett (potenciálisan) megismer(het)i az ajánlat tartalmát. Nem válik el tehát egymástól sem az ajánlat, sem az ajánlati kötöttség, sem pedig a hatályosság - azok egyszerre jelentkeznek.

\section{Az ajánlati kötöttség kérdése a Ptk. szerinti versenyeztetési és közbeszerzési eljárásban}

Kérdésként merül fel, hogy vagyon ugyanez-e a helyzet eljárásjogilag is? Igaz-e, hogy:

[ajánlattételi határidő lejárta] $=$ [ajánlati kötöttség beállta $]=$ [ajánlat hatályossá válása]?

Számít-e itt az időbeliség, ha az alapesetben ennek - úgy tünik (mint látni fogjuk, tévesen) - nincs jelentősége?

Versenyeztetési eljárásban az első egyenlet az alábbiak szerint megerősítést nyer, miközben a hatályossá válás kapcsán nem kapunk az alapesettől eltérő meghatározást.

6:75. \& [Ajánlati kötöttség versenyeztetési eljárásban]

(1) Az ajánlati kötöttség a felhívásban megjelölt határidő lejártával kezdődik. Az ajánlattevő ajánlatát e határidő lejártáig módosíthatja vagy visszavonhatja.

A közbeszerzési eljárásban is ajánlattételi határidő kerül előírásra, azonban két eset különböztethető meg egymástól:

1) [ajánlattételi határidő lejárta] = [ajánlati kötöttség beállta]

2) [ajánlattételi határidő lejárta] ₹ [ajánlati kötöttség beállta]

Nyilván a 2) eset érdemel magyarázatot, hiszen ez az ajánlat Ptk. szerinti fogalmának elvetésével jár, mivel az ajánlattételi határidő lejártával a megtett ajánlat nem „kötött”. Beszélhetünk-e ez esetben egyáltalán ajánlatról?

A Kbt. 87. §-a a tárgyalásos eljárásban írja elő az első, ajánlati kötöttséggel nem terhelt ajánlat megtételét az alábbiak szerint:

(3) $\mathrm{Az}$ első ajánlat benyújtására vonatkozó ajánlattételi határidó meghatározására a 84. \& (4)-(8) bekezdését kell alkalmazni.

(4) A tárgyalásos eljárásban az ajánlatkérő a közbeszerzési dokumentumokban meghatározott feltételekhez, az ajánlattevő az ajánlatához a tárgyalások befejezésének időpontjától van kötve. [...]

(6) Az ajánlatkérö, ha az eljárást megindító vagy meghirdetö felhívásban jelezte, hogy fenntartja ennek a lehetóségét, az első ajánlatok beérkezését követöen dönthet úgy, hogy nem tart tárgyalást, hanem a benyújtott ajánlatok birálatával és értékelésével befejezi az eljárást. Ebben az esetben döntéséröl haladéktalanul értesíti az ajánlattevöket, az ajánlattevő ajánlati kötöttsége az értesítés ajánlatkéró általi megküldésével áll be, az ajánlatkérő által - a (4) bekezdésben foglalt maximális időtartamok alkalmazásával - meghatározott idöre. 


\section{(7) Tárgyalásos eljárásban kötelező végleges ajánlat benyújtása,} amennyiben az ajánlatkérő nem él a (6) bekezdésben foglalt lehetöséggel Láthatjuk tehát, hogy az első ajánlat a tárgyalási alap, amely alapján tárgyalhatnak az ajánlattevővel, majd egy végleges ajánlat megtételére kerül sor, amely már kötöttséggel terhelt. Az első ajánlat megtételének tehát eljárásjogilag nagy jelentősége van, mivel anélkül egyrészt nem tárgyalhat ajánlattevő és végleges ajánlatot sem tehet, másrészt az első ajánlat az ajánlatkérő döntése alapján kötöttséget szerezhet a Kbt. 87. § (6) bekezdése szerint.

Megemlíthetjük továbbá az elektronikus árlejtés intézményét, amelynek "során az ajánlattevók új, - egyre csökkenő - árakat, illetve az ajánlat egyes számszerüsithető elemeire vonatkozó új értékeket ajánlanak"4, vagyis lényegében új ajánlatokat tesznek. Az ajánlattevők ajánlati kötöttsége főszabály szerint az árlejtés lezárásakor áll be ${ }^{5}$.

\section{A hatályosság kérdése a Ptk. szerinti versenyeztetési és közbeszerzési eljárásban}

A továbbiakban érdemes megvizsgálni azt, hogy az ajánlati kötöttség sajátos szabályaihoz képest hogyan ítélendő meg az ajánlat hatályossá válása, vajon eltérő logika érvényesül-e? Az ajánlat hatályossá válása kapcsán szintén két lehetséges eset vázolható fel:

1) [ajánlattételi határidő lejárta] ₹ [ajánlat hatályossá válása], vagyis az ajánlat a megtétellel válik hatályossá

2) [ajánlattételi határidő lejárta] = [ajánlat hatályossá válása], vagyis a megtett ajánlat az ajánlattételi határidő lejártával válik hatályossá

Abban az esetben, ha az (első) ajánlat megtételével a kötöttség sem áll feltétlenül be, úgy érvelhetnénk a mellett is, hogy nem az ajánlattételi határidő lejárta számít a hatályosság szempontjából sem, hanem az ajánlat megtétele.

Meglátásom szerint ez az állítás csak az elektronikus árlejtés során megtett ajánlattételre alkalmazható az árlejtés eltérő logikája miatt, hiszen ez esetben nem egy ajánlattételi határidő van ameddig ajánlattevőnként egy ajánlatot kell benyújtani, hanem az árlejtésnek van egy időtartama, amelynek során az ajánlattevő́k hatályos ajánlato(ka)t tehetnek azzal, hogy az újabb (és persze hatályos) ajánlattal a korábbi ajánlatuk hatályát veszti.

Most pedig nézzük meg azokat az érveket, amelyek alátámasztják azt az állitást, hogy főszabályként miért nem az ajánlattétellel válik hatályossá az ajánlat.

Először is praktikusan kezelhetetlen, ha az ajánlattételi határidőtől függetlenül például a határidő lejárta után 2 évvel - megtett ajánlat hatályosulhatna, miközben az az ajánlat a célját soha nem érheti el az elkésettsége miatt. Ha viszont valamilyen korlátot állítunk a hatályossá válás elé, úgy már nem igaz az állítás, hogy az tisztán a megtétellel hatályosulna.

\footnotetext{
${ }^{4}$ Kbt. 108. § (1) bekezdés

5 424/2017. (XII. 19.) Korm. rendelet az elektronikus közbeszerzés részletes szabályairól, 31. § (2) bekezdés
} 
Másodszor azt is felvethetjük, hogy amennyiben zárt csomagolásban kell az ajánlatot benyújtani, úgy adott esetben egy üres csomag kerülhet ajánlatként benyújtásra és felbontásra, vagyis a megtételkor egy ál/látszat-ajánlat válna hatályossá, ami sem az ajánlat, sem pedig a hatályosság (egymással összefüggő) fogalmával nem igazolható.

Fontos megállapítani végül a Ptk. 6:75 § (1) bekezdésének második mondata alapján („Az ajánlattevő ajánlatát e határidő lejártáig módosithatja vagy visszavonhatja. "), hogy a határidő lejárta elött megtett ajánlat függő jogi státuszban van, mert szabadon módosítható/visszavonható, ami a határidő lejártát követően már nem megengedett.

A függő jogi helyzet azonban nyilvánvalóan nem összeegyeztethető a hatályossággal, ahogyan egy már kihirdetett, de még függő helyzetben lévő jogszabály, vagy egy megkötött, de a hatálybalépés tekintetében feltételhez kötött szerződés is éppen a hatálybalépéssel veszíti el függő jellegét.

Összességében tehát azt mondhatjuk, hogy az eljárásjogilag releváns címzetti tudomásra jutás - amire a jognyilatkozat hatályossá válásánál utaltunk - a határidő lejártához kötődik, vagyis függetlenül a kötöttség beálltától abban a pillanatban válik hatályossá a megtett ajánlat, amikor az ajánlattételi határidő lejárt.

$A z$ ajánlattétel szempontjából az ajánlat hatályossága, illetőleg létezése az alábbiak szerint vázolható fel a versenyeztetési/közbeszerzési eljárásban:

- "ajánlat" nem-előírásszerű megtétele = nem létezik és nem hatályosul ajánlat. Ilyen eset például, ha az előírt elektronikus ajánlattétel helyett papír alapon nyújtják be az ajánlatot ajánlatkérőnek.

- "ajánlat" előírásszerű módon való megtétele = létezhet és hatályosulhat (adott esetben) az ajánlat. Az előírt csomagolásban benyújtják az ajánlatot a megadott helyre és határidőben, de annak tartalma nem ismert - lehet, hogy nincs benne ajánlat.

- ajánlat előírásszerü módon és tartalommal való megtétele = létezik ajánlat és hatályosul a határidő lejártakor (és az esetek többségében a kötöttség is beáll). Az ajánlat hatályossága és létezése tehát egymástól nem elválasztható a versenyeztetési/közbeszerzési eljárásban, vagyis egy hatálytalan ajánlat nemlétezőnek minősül, ezért nem is minősíthető érvénytelenséggel.

A fentiek alapján az is megállapítható, hogy az ajánlat hatályossá válása feltételhez kötött:

- ajánlatkérő felhívása alapján, és

- az ajánlatkérő és a jogszabályok által meghatározott minimális feltételeknek eleget téve

- válhat hatályossá a megtett ajánlat.

A feltételrendszer vonatkozik

- az ajánlattétel módjára (határidőben, az előírt helyre/formában/technikai feltételeknek megfelelően)

- az ajánlat tartalmára (a közbeszerzési ajánlat-fogalomnak megfelelően). 


\section{Az ajánlat hatálytalanná válása}

Nemcsak az vizsgálandó, hogy hatályos ajánlat került-e benyújtásra, hanem az is, hogy az elbírálandó (adott esetben nyertes) ajánlat hatályos-e még. Térjünk vissza ismét a kályhához, és nézzük meg, mint mond a Ptk. a jognyilatkozat hatálytalanságáról.

6:9. \& [A szerződés szabályainak megfelelő alkalmazása]

A jognyilatkozat hatályára, érvénytelenségére és hatálytalanságára - ha e törvény eltéröen nem rendelkezik - a szerződés általános szabályait kell megfelelöen alkalmazni.

6:119. \& [A hatálytalan szerződés joghatása]

(1) Ha a szerződés hatálya nem állt be, vagy a szerződés hatályát vesztette [...] a szerzödés teljesítése nem követelhetö.

A Ptk. alapján az szűrhető le, hogy a hatálytalan ajánlat, mint szándéknyilatkozat a szerződéshez hasonlóan - nem számonkérhető, vagyis jogi relevancia hiányában nem létezőnek tekintendő.

Kérdés azonban, hogy miképpen következhet be a közbeszerzési eljárásban a hatályvesztés? Mivel egy eljárásban megtett egyoldalú jognyilatkozatról van szó, ezért meglátásom szerint alapvetően

- ajánlattevő által:

- az ajánlat visszavonásával

- új, hatályos ajánlat megtételével

- ajánlatkérő (esetleg hatóság/bíróság) által:

○ az ajánlat hatályának eljárásjogi megszüntetésével

- meghatározott jogi tény bekövetkeztével:

○ az ajánlat hatályának eljárásjogi megszünésével ${ }^{6}$

lehetséges.

A főbb dogmatikai tanulságokat, és a további releváns kérdéseket a tanulmány soron következő pontjaiban szeretném összefoglalni.

\section{Nemlétező és hatálytalan - létező és hatálytalan}

Először is érdemes rámutatni arra a megfigyelésre, hogy az ajánlat, illetve az egyéb egyoldalú jognyilatkozat hatályosságának hiánya - eljárásjogilag - a nemlétezését jelenti, ami nem feltétlenül magától értetődő, hiszen van olyan jogintézmény (pl.: a szerződés), amely jogszerüen létrejöhet (pl. a szerződés megköthető), azonban nem lép egyből hatályba:

Ptk. 6:116. \& [Feltétel és időhatározás]

(1) Ha a felek a szerződés hatályának beálltát bizonytalan jövőbeli eseménytöl tették függővé, a szerződés hatálya a feltétel bekövetkeztével áll be.

A hatálytalanság egyik esetében tehát nem beszélhetünk ajánlatról (csak jogilag nemlétező ajánlatról, amely ezért joghatást sem válthat ki - lásd lentebb), míg a

\footnotetext{
${ }^{6}$ Például más ajánlattevő új, kedvezőbb ajánlata által - lásd: Ptk. 6:76. § (2) bekezdés.
} 
másik esetben a jogilag kifogástalan (vagy éppen érvénytelen) szerződés a célzott joghatását (ti. a szerződés jogszerű teljesülését) nem képes a feltétel bekövetkeztéig (vagy adott esetben utána sem) kiváltani.

Megállapítható tehát, hogy elsősorban az egyes jogügyletek lét(rejött)e vizsgálandó, amely bizonyos esetekben közvetlen összefüggésben van a hatálytalansággal, más esetekben viszont nem.

\section{Nemlétező és hatálytalan - létező és érvénytelen}

Az egzisztenciális kérdés megválaszolásásának primátusa mindkét ismertetett esetben hátrébb rangsorolja az érvénytelenség szempontját.

Az első esetkörben (ti. amikor a hatálytalanság nemlétezéssel azonosítható) a hatályosság kérdése elsődleges az érvénytelenség szempontjával szemben, vagyis bármilyen, az érvénytelenségre vonatkozó elöírás vizsgálata csak a hatályosságra vonatkozó pozitív eredmény megállapítását követően vetődhet fel.

Ugyanakkor a második esetkörben is alárendelt szerepet játszik az érvényesség kérdése a létezés szempontjához képest. Egy másik jogterületről vett példán szemléltetve: egy jogszerűen elfogadott, majd csak a napilapban "kihirdetett" jogszabály nem érvénytelen, hanem nemlétező jogszabálynak minősül annak köszönhetően, hogy nem érvénytelen, hanem nemlétező kihirdetés történt, mivel a jogszabály napilapban történő közzététele a kihirdetés jogi fogalmába nem sorolható7. Mindez attól függetlenül is megállapítható, hogy a szóban forgó jogszabály hatálybalépése tervezetten csak a jövőben várható (pro futuro hatálybalépés).

Megkülönböztetendő tehát az a „látszat-jogi” jelenség, amit a jog nemlétezőnek tekint attól, amit létezőnek, de érvénytelennek tart.

Hasonló következtetést vonta le Siklósi Iván is a nemlétező, érvénytelen és hatálytalan jogügyletekről írt monográfiájában ${ }^{8}$, melyben a jogügyletek négyféle lehetséges állapotát (szintjét) különbözteti meg, melyek közül az

1. szint „a jogügylet nemlétezése, amikor is a jogügylet minden vonatkozásában alkalmatlan jogügyleti joghatások kiváltására", a

2. szint "a létező jogügylet érvénytelensége, amely azt jelenti, hogy a külsó tényállással rendelkezó jogügylet elvben sem válthatja ki a kivánt joghatásokat, mert a jogrend ezzel szankcionálja a jogrendbe ütközö jogügyletet".

\footnotetext{
${ }^{7}$ A példát Jakab András egyik tanulmányából vettem (JAKAB András: Jogszabályok érvényessége, hatálya és alkalmazhatósága. http://jesz.ajk.elte.hu/jakab6.html\#_ftnref37 - letöltve: 2020.12. 07), aki szerint a hiba érvénytelenséget jelent. Jakab nem ismeri fel, hogy a nemlétezés folytán az érvénytelenség megállapítása dogmatikailag hibás, hiszen az érvényesség-szempontú vizsgálat (és így az érvénytelenségről hozott döntés) nem értelmezhető egy nemlétező jogszabály kapcsán. Úgy is fogalmazhatnánk, hogy nem beszélhetünk érvénytelen jogszabályról abban az esetben, ha jogszabályról sem beszélhetünk legfeljebb egy újságcikkről.

8 Sikıósi Iván: $A$ nemlétező, érvénytelen és hatálytalan jogügyletek elméleti és dogmatikai kérdései a római jogban és a modern jogokban, ELTE Eötvös Kiadó, Budapest, 2014

${ }^{9}$ SIKLósI i. m. 388. o.
} 
Érdekes, hogy Siklósi az 1. szint kapcsán jogügyletröl értekezik (amely minden vonatkozásában alkalmatlan jogügyleti joghatások kiváltására), noha jogi nemlétezése folytán az éppen jogügyletként nem minősíthetö ${ }^{10}$, legfeljebb jogügyletre hasonlító - ügyletként.

Kifogásolhatónak gondolom Siklósi azon állítását is, mely szerint az érvénytelen jogügylet e/vben sem válthatja ki a kívánt joghatást.

Vegyük szemügyre az állításom alátámasztására a következő - a szerződésszerü teljesítést követően jogilag nem támadott - jogeseteket:

\begin{tabular}{|c|c|c|}
\hline & Jogesetek leírása & Jogesetek minősítése \\
\hline 1. & $\begin{array}{l}\text { a jogellenes fenyegetés hatására } \\
\text { megkötött szerződést az arra jogosult nem } \\
\text { támadja meg, ezért érvénytelensége nem } \\
\text { kerül bíróság által megállapításra és a } \\
\text { szerződést a felek teljesítik }\end{array}$ & $\begin{array}{l}\text { az implicite érvénytelen, de } \\
\text { explicite nem érvénytelen } \\
\text { szerződés érvényesként } \\
\text { tekintett szerződésként } \\
\text { teljesül }\end{array}$ \\
\hline 2. & a semmis szerződést a felek teljesítik & $\begin{array}{l}\text { az érvénytelen szerződés } \\
\text { érvénytelen szerződésként } \\
\text { teljesül }\end{array}$ \\
\hline 3. & $\begin{array}{l}\text { a semmis szerződés más szerződés } \\
\text { érvényességi kellékeinek megfelel, amely } \\
\text { a szerződő felek feltehető szándékával } \\
\text { nem ellentétes, úgy az utóbbi szerződés } \\
\text { érvényes (a Ptk. 6:88. } §(2) \text { bekezdés } \\
\text { szerinti conversio), a felek pedig az } \\
\text { érvényes szerződést teljesítik }\end{array}$ & $\begin{array}{l}\text { az érvénytelen szerződés } \\
\text { helyett végül érvényes } \\
\text { szerződés teljesül }\end{array}$ \\
\hline 4. & $\begin{array}{l}\text { az érvénytelen szerződést a bíróság a } \\
\text { szerződés megkötésének időpontjára } \\
\text { visszamenő } \quad \text { hatállyal érvényessé } \\
\text { nyilvánítja (Ptk. } 6: 110 \text {. §), a felek pedig az } \\
\text { érvényessé nyilvánított szerződést } \\
\text { teljesítik } \\
\end{array}$ & $\begin{array}{l}\text { az érvénytelen szerződés } \\
\text { végül } \\
\text { szerződésként teljesül }\end{array}$ \\
\hline 5. & $\begin{array}{l}\text { a szerződés a felek akaratából érvényessé } \\
\text { válik (Ptk. 6:111. §), a felek pedig az } \\
\text { érvényessé vált szerződést teljesítik }\end{array}$ & \\
\hline
\end{tabular}

Meggyőző érvvel kellene meglátásom szerint cáfolni, hogy az (implicite, vagy explicite is) érvénytelen szerződés jogi kifogás nélküli teljesülése ne jelentené a joghatás bekövetkeztét (1. és 2 . eset), míg a 3. jogesetben az érvénytelen szerződés kívánt joghatása megegyezhet az érvényes szerződés - teljesült - joghatásával.

\footnotetext{
10 Meglátásom szerint Siklósi csupán terminológiai pontatlanságot követ el, hiszen a "nemlétezőnek" minősítés folytán ő sem gondolja, hogy jogügyletról lenne szó, ugyanakkor úgy tünik számomra, hogy éppen ez mutat rá arra a felvetésre, hogy a külső tényállás kérdésköre egyáltalán nem csak a 2. szint kapcsán merül fel, hiszen „valamiért” már az 1. szint kapcsán is nemlétező jogügyletről beszélünk, vagyis az ügylet olyan külső tényállással rendelkezik, amely a jogügyleti státuszát felveti, de nem biztosítja.
} 
A használható érv azon alapulhat, hogy a célzott joghatás a szerződési kötőerővel (ti., hogy a felek a szerződést kölcsönösen, kötelezően teljesítsék) és az állami kikényszeríthetőséggel azonosítandó ${ }^{11}$, melyekről érvénytelen szerződések esetén nem beszélhetünk.

Mindazonáltal úgy vélem, hogy a két komponens végső soron instrumentális, és ezért alárendelt szerepet játszhat a szerződés jogilag elfogadott (de legalábbis nem kifogásolt) teljesülése esetén, hiszen sem a kötőerőnek, sem az állami kényszernek nincs már ekkor relevanciája, azok a szerződésszerü teljesítést csupán elősegítik (azt indukálják/garantálhatják), de nem okozzák.

A 4. és 5. eset pedig arra mutat rá, hogy mennyire alapvető a statikus szemléletmód helyett a jog folyamatszerüségét tudatosítani, hiszen ami kezdetben definíció-szerüen és kizárólagosan egyféleképpen ítélendő meg, az egy későbbi időés tényállapotban gyökeresen eltérő jogi minősítést nyerhet.

A fentiek alapján talán nem túlzás hibásnak minősíteni azt a kategorikus állítást, hogy a jog az érvénytelen jogügylettől feltétlenülmegtagadná a célzott joghatást.

\section{Létező és hatályossá váló - az időtényező újragondolása}

Mind az utóbb említett jogesetek, mind az ajánlattételi határidő és a hatályosság összefüggésének korábbi tárgyalása rámutat arra a tényre, hogy az idő milyen alapvető fontossággal bír a jog területén.

A hatályosság kérdésköre azonban nem csak a közbeszerzési jog revízióját vet(heti)i fel, hanem többek között a Ptk. időszemléletét is. A tanulmány ezen (záró) fejezete erre kívánja felhívni a figyelmet az alábbiak szerint.

Nem vitatható, hogy a korábbi Ptk. dogmatikai rendszeréhez képest fejlődésként tekinthetünk a 2013. évi Ptk.-ra abban a tekintetben, hogy a "tételes jogi szabályozás szintjén világos különbséget tesz a szerződés létrejötte, érvényessége és hatályossága között. ${ }^{12 " ~}$

Vizsgáljuk meg a változást egy jól demonstrálható tárgykörben. Az 1959. évi IV. törvény (a továbbiakban rPtk.) 215. §-a a következőképpen rendelkezett:

„(1) Ha a szerződés létrejöttéhez harmadik személy beleegyezése vagy hatósági jóváhagyás szükséges, ennek megtörténtéig a szerződés nem jön létre, de a felek nyilatkozatukhoz kötve vannak. Kötöttségétöl bármelyik fél szabadul, ha az általa a másik féllel közölt megfelelö határidőn belül a harmadik személy a beleegyezés, illetöleg a hatóság a jóváhagyás felöl nem nyilatkozik.

(2) A beleegyezés, illetöleg a jóváhagyás megtörténtével a szerződés - ha jogszabály kivételt nem tesz - megkötésének időpontjától kezdődő hatállyal jön létre."

A hatályos Ptk. vonatkozó szabályai a következők:

„6:118. \& [Beleegyezéstől vagy jóváhagyástól függő szerződés]

${ }^{11}$ Kötelmi jog I. a 2013. évi V. törvény alapján (szerk.: Csehi Zoltán), Menedzser Praxis, Budapest, 2014, 89. 0.

12 Kötelmi jog I. a 2013. évi V. törvény alapján (szerk.: Dr. Csehi Zoltán), Menedzser Praxis, Budapest, 2014, 53. o. 
(1) Ha a szerződés hatályosságához jogszabály harmadik személy beleegyezését vagy hatóság jóváhagyását teszi szükségessé, a beleegyezéssel vagy a jóváhagyással a szerződés megkötésének időpontjára visszamenőleg válik hatályossá."

Jól látható tehát, hogy a beleegyezés/jóváhagyás (helyesen) már nem a szerződés létrejöttét, hanem a hatályossá válását eredményezi, azonban megkérdőjelezhető módon továbbra is ex tunc, vagyis visszamenőleges hatállyal. Miért kifogásolható ez? Fontos megállapítani, hogy a visszamenőleges rendezés szükségességét/indokoltságát mindenekelött a szabályozás megalkotójának kellene meggyőző módon alátámasztania.

Meglátásom szerint ez nem azért nem járhat végső soron sikerrel, mert tiltott lenne a múlt jogi átminősítése - ennek elvi akadálya alapvetően nincsen -, hanem azért, mert dogmatikailag hibás a hatályosságot visszamenőlegesen megítélni ${ }^{13}$ : a hatályosság éppen akkor állhat be, amikor a függő feltétel megszünik - előtte nincs értelme hatályosságról beszélni. Ez akkor is így van, ha jogilag - talán a rossz berögződés miatt - újra akarjuk írni a múltat egy hibás és felesleges fikcióval.

A hiba szemléltetésére elégséges az alábbi példa: egy megkötött vállalkozási szerződés szerint a hatálybalépésétől számított 25 nap alatt kellene a vállalkozónak teljesítenie a szolgáltatást, de a hatóság csak a szerződés megkötésétől számított 30. napon hagyja jóvá a szerződést és léphet hatályba a szerződés. Mivel úgy kell tekinteni a jóváhagyást követően, mintha a szerződés a megkötés időpontjában már hatályossá vált volna, így a hatálybalépéstől - vagyis a megkötéstől - számított 25 napos teljesítés lehetősége ellehetetlenült. Hozzátehetjük: még ha lenne is elegendő ideje a vállalkozónak a teljesítésre, a Ptk. által előírt időugrás így is indokolatlanul hátrányosan érintené.

A fikció szükségtelenségét - úgy vélem - különösebben nem kell magyarázni, hiszen a beleegyezés/jóváhagyás hatályossá válásával történő hatálybalépés se a felekre, se harmadik személyre nézve nem járna hátrányos jogkövetkezménnyel, ezért az alkalmazása nem csak hogy nem volna káros, de dogmatikailag éppen, hogy kívánatosnak tekinthető.

\section{Irodalomjegyzék}

- CSEHI Zoltán (szerk.): Kötelmi jog I. a 2013. évi V. törvény alapján, Menedzser Praxis, Budapest, 2014

- JAKAB András: Jogszabályok érvényessége, hatálya és alkalmazhatósága. http://jesz.ajk.elte.hu/jakab6.html\#_ftnref37 (Letöltés időpontja: 2020. december 7.)

- MÁTÉ Gergő: Mi az ajánlat?, Közbeszerzési Szemle, 2017/1-2., 64-82. o.

- Sikıósi Iván: $A$ nemlétezó, érvénytelen és hatálytalan jogügyletek elméleti és dogmatikai kérdései a római jogban és a modern jogokban, ELTE Eötvös Kiadó, Budapest, 2014

\footnotetext{
13 Természetesen más az az eset, amikor később születik bírói döntés arról, hogy egy korábban nem hatályosként „kezelt" szerződés jogilag (helyesen) hatályosként minősül.
} 